\title{
Redescription of Arctosa ravida Ponomarev, 2007 (Aranei: Lycosidae), with the first description of the male
}

\section{Переописание Arctosa ravida Ponomarev, 2007 (Aranei: Lycosidae), с первоописанием самџа}

\author{
Alexander V. Ponomarev, Vladimir Yu. Shmatko \\ А.В. Пономарёв, В.Ю. Шматко
}

Southern Scientific Centre RAS, Chekhov str., 41, Rostov-on-Don 344006 Russia. E-mail: ponomarev1952@mail.ru Южный научный центр РАН, пр. Чехова, 41, Ростов-на-Дону 344006 Россия.

KEY WORDS: Araneae, Caspian lowland, distribution, spider, taxonomy.

КЛЮЧЕВЫЕ СЛОВА: Araneae, паук, Прикаспийская низменность, распространение, таксономия.

ABSTRACT. Based on the paratype female and new material from the Caspian lowland, illustrated redescription of Arctosa ravida Ponomarev, 2007 is given. The male is described for the first time. This species belongs to the cinerea species group and is closest to the West Mediterranean A. similis Schenkel, 1938.

How to cite this article: Ponomarev A.V., Shmatko V.Yu. 2019. Redescription of Arctosa ravida Ponomarev, 2007 (Aranei: Lycosidae), with the first description of the male // Arthropoda Selecta. Vol.28. No.4. P.579-581. doi: 10.15298/arthsel. 28.4.12

РЕЗЮМЕ. На основе изучения паратипа-самки и нового материала из Прикаспийской низменности приводится иллюстрированное переописание Arctosa ravida Ponomarev, 2007. Самец описан впервые. Вид входит в группу видов cinerea и наиболее близок к западно-средиземноморскому A. similis Schenkel, 1938.

\section{Introduction}

The genus Arctosa C.L. Koch, 1847 contains about 170 valid species in the world fauna [WSC, 2019]. In Europe, 23 species (with two subspecies) have been recorded/described to date [Nentwig et al., 2019], of which seven Arctosa species have been found in the Caspian lowland: viz., A. cinerea (Fabricius, 1977), A. leopardus (Sundevall, 1832), A. personata (L. Koch, 1872), A. pseudoleopardus Ponomarev, 2007, A. stigmosa (Thorell, 1875), A. tbilisiensis Mcheidze, 1947 and $A$. ravida Ponomarev, 2007 [Ponomarev, 2011a, b; Ponomarev, Abdurakhmanov, 2014; Ponomarev et al., 2017]. A. ravida was described from two females from the Volga-Ural sands and the valley of Ural River (Western Kazakhstan) [Ponomarev, 2007]. Later, this species, including its males, was found in Dagestan (on the islands of Tyuleniy and Chechen') and Mangystau Region of Kazakhstan [Ponomarev et al., 2011a; Ponomarev, Abdurakhmanov, 2014]. However, a formal de- scription of the male was not provided. Below we present a redescription of $A$. ravida, with the first description of the male.

\section{Material and methods}

The material used in the work was collected from the Caspian lowland in the territory of Kazakhstan (Atyrau and Mangistau Regions) and Russia (the Republic of Dagestan) in 1986-2013 (Map). The studied material is shared between the personal collection of A.V. Ponomarev (CP) and the collection of Zoological Museum of the Moscow State University (ZMUM; curator K.G. Mikhailov).

Photographs were taken at the Southern Scientific Center of the RAS by means of a microscope MIKMED-6 with a Sony NEX-C3 $16.2 \mathrm{mp}$ digital camera and microphoto-adapter (MFN-12).

The terminology of the copulatory organs follows Buchar et al. [2006]. All measurements are in $\mathrm{mm}$.

\section{Description}

Arctosa ravida Ponomarev, 2007

Figs 1-10, Map.

Arctosa ravida Ponomarev, 2007: 3, fig. 1 (+).

TYPE: Paratype female (CP: 25.17.4/2) from Kazakhstan, Atyrau Region, c. $18 \mathrm{~km}$ NNE Makhambet Vil., sand hills with tamarisk (Tamarix sp.), sandy wormwood (Artemisia arenaria) and ephemera in the left-Bank floodplain of Ural River, 10.04.1986, A.V. Ponomarev.

MATERIAL. KAZAKHStan. Mangistau Region: $1 \sigma^{\gamma}, 1$ q (CP: 25.17.4/5), 8-12 km South of Fort Shevchenko, coast of Tyub-Karagan peninsula, 10-11.06.2013, G.M. Abdurakhmanov. RUSSIA. Dagestan: 1 \& (ZMUM), Kizlyar Distr., Tyuleniy island, pitfall traps, 22-26.06.2011, S.V. Aliyeva; 3 우 (CP: 25.17.4/3), Makhachkala, Chechen' island, pitfall traps, 17-21.06.2011, S.V. Aliyeva; $3 \sigma^{7} \sigma^{7}, 87$ 우 (CP: 25.17.4/4), the same locality, 2531.05.2012, Z.A. Magomedova; $4 \sigma^{\top} \sigma^{\top}$ (ZMUM), $4 \sigma^{\top} \sigma^{\top}, 1$ \& (CP: 25.17.4/6), Makhachkala, Sarykum sand dune, 26.04.2012, G.M. Khabiev; $4 \sigma^{7} \sigma^{7}$ (CP: 25.17.4/7), the same locality, 27.09.2013, G.M. Khabiev. 


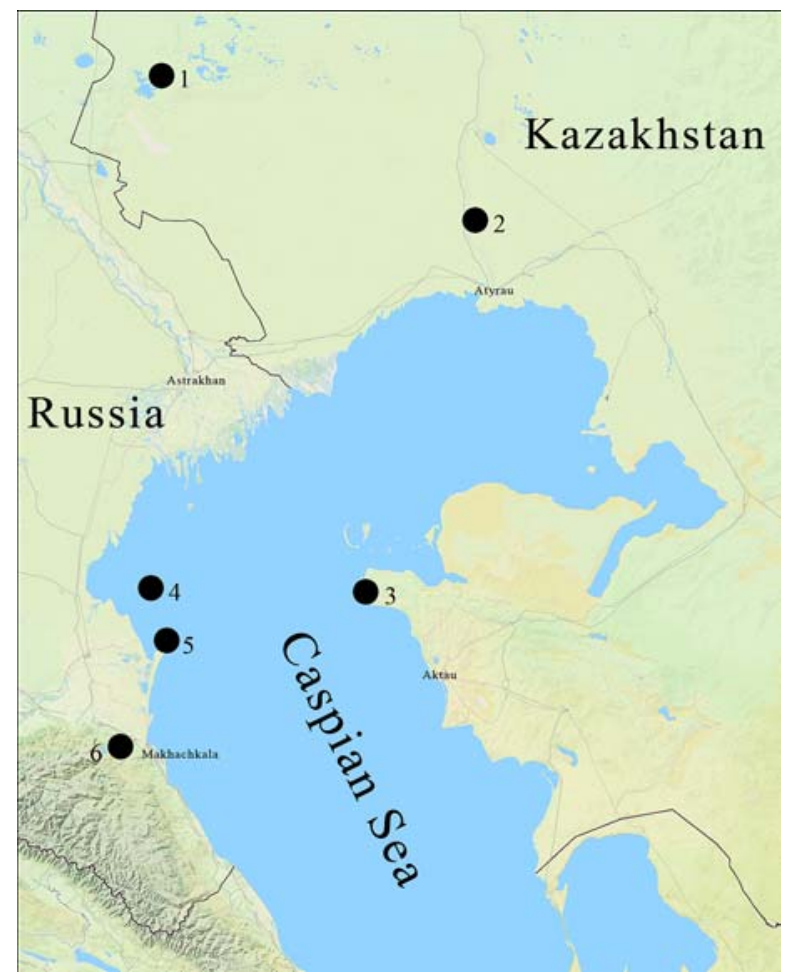

Map. Collecting localities of Arctosa ravida in Kazakhstan (1 - Aybas, 2 - Makhambet, 3 - Tyub-Karagan Peninsula) and Russia (4 - Tyuleniy island, 5 - Chechen' island, 6 - Sarykum sand dune).

Карта. Точки находок Arctosa ravida в Казахстане (1 Айбас, 2 - Махамбет, 3 - п-ов Тюб-Караган) и России (4 о. Тюлений, 5 - о. Чечень, 6 - бархан Сарыкум).

DIAGNOSIS. A. ravida belongs to the cinerea species group. By the conformation of the copulatory organs, it is closest to the Western Mediterranean A. similis Schenkel, 1938 (cf. figs 19, 20, 27-30 in Buchar et al. [2006]), from which it can be easily distinguished by a larger length/width ratio of the tibiae in the male palps, the long and narrow cymbium, the shape of tegular apophysis and the presence of a keel-shaped median septum of the epigyne. By the structure of the embolar division and epigyne, A. ravida is also similar to the European A. perita (Latreille, 1799) (cf. figs 8, 23, 24 in Buchar et al. [2006]), but can be easily distinguished from it by the much larger body size, different coloration and the shape of cymbium and median septum.

DISTRIBUTION. The Caspian lowland and islands of Northern Caspian Sea (Map). The species has been recorded from the following localities: Kazakhstan: Aybas, Makhambet, Tyub-Karagan Peninsula [Ponomarev, 2007; Ponomarev, Abdurakhmanov, 2014]; Russia, Dagestan: Tyuleniy and Chechen' islands [Ponomarev et al., 2011a; Ponomarev, Abdurakhmanov, 2014].

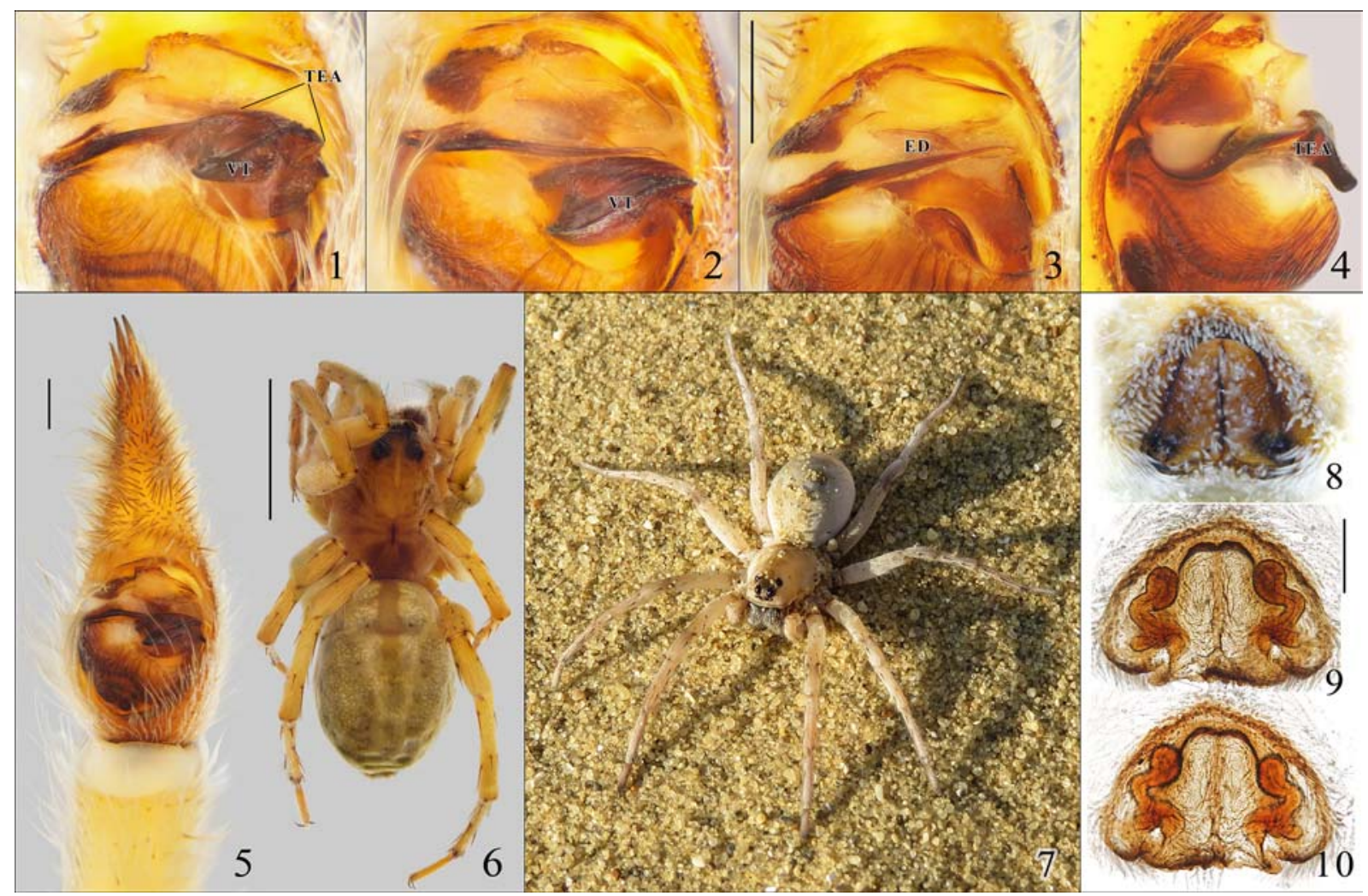

Figs 1-10. Habitus and copulatory organs of Arctosa ravida: 1 - bulbus, ventral view; 2 - bulbus, ventral-apical view; 3 - bulbus without tegular apophysis, ventral view; 4 - bulbus, prolateral view; 5 - male palp, ventral view; 6 - female, paratype; 7 - female, Sarykum sand dune; 8, 9- epigyne, ventral view; 10 - vulva , dorsal view. Scale bars: 1-5, 8-10 (0.25 mm), 7 (5 mm). Abbreviations: ED - embolic division; TEA - tegular apophysis; VT - ventral toot of the tegular apophysis.

Рис. 1-10. Габитус и копулятивные органы Arctosa ravida: 1 - бульбус вентрально; 2 - бульбус вентро-апикально; 3 бульбус без тегулярного отростка, вентрально; 4 - бульбус ретролатерально; 5 - пальпа самца вид снизу; 6 - самка, паратип; 5 самка, бархан Сарыкум; 8, 9 - эпигина вентрально; 10 - вульва дорсально. Масштаб: 1-5, 8-10 (0,25 мм), 7 (5 мм). Сокращения: $\mathrm{ED}$ - эмболюсный отдел; TEA — тегулярный отросток; VT — вентральный зубец тегулярного отростка. 
HABITAT. Open sands, often far from water bodies.

DESCRIPTION. MALE. Large spider. Total length 14.118.1, carapace length 6.4-7.6, width 4.8-5.3. Carapace, legs, palps yellow; tibia, metatarsus and tarsus I, II darkened. Legs without dark rings and spots. Legs, tibia of palpus and cymbium covered with long white hairs. Tarsal claws very large. Chelicerae dark brown. Abdomen dorsally light yellow, with a medial gray-yellow cardiac mark extending from the anterior edge to its middle. Male palpal tibia three times longer than broad. Cymbium narrow and long, with 5-6 large claws at its tip. Cymbium length 2.75 times bigger than its width. Length of the free apical part of cymbium 1.5 times larger than the bulbus diameter (Fig. 5). Tegular apophysis is well-developed (Figs 1, 2, 4), its ventral tooth long, well-pronounced (Figs 1,2).

FEMALE. Total length 13-17, carapace length 5.5-7.7, width 4.2-6.2. Overall body colour yellow (Figs 4, 5). Carapace with a well-defined medial groove. There are subtle grey radial stripes departing from the medial groove and reaching the carapace edges. Abdomen with indistinct gray spots besides cardiac yellow mark; some females without such gray spots. Epigyne trapezoidal (Figs 8, 9), its width equal to length or slightly longer. Epigynal margins markedly sclerotized. Septum narrow, keel-shaped (Fig. 8). The rear epigynal edge with small teeth. Insemination ducts curved, with receptacles not reaching the anterior margin of the epigyne (Fig. 10).

Acknowledgements. The authors are grateful to the colleagues from Makhachkala (Republic of Dagestan): G.M Abdurakhmanov, S.V. Aliyeva, Z.A. Magomedova and G.N. Khabiyev, for allowing us to examine their spider materials. We wish to thank E.V. Ilyina (Makhachkala) for the photo of live female of $A$. ravida from the Sarykum sand dunes. Our cordial thanks go to Dmitry A. Dubovikoff (Department of Applied Ecology, Faculty of Biology, St. Petersburg University) for the translation of the ms into the English. The work was supported by the government contract for the
Southern Scientific Centre of the RAS, project AAAA-A19119011190176-7.

\section{References}

Buchar J., Knoflach B., Thaler K. 2006. On the identity of Arctosa variana C.L. Koch and Arctosa similis Schenkel, with notes on related species (Araneae: Lycosidae) // Bulletin of the British Arachnological Society. Vol.13. Pt.9. P.329-336.

Nentwig W., Blick T., Gloor D., Hänggi A., Kropf C. 2019. Spinnen Europas. Version 03.2019. Online https://www.araneae. nmbe.ch, accessed on 15.03.2019. doi: 10.24436/1

Ponomarev A.V. 2007. [New spiders (Aranei) from the south-east of Europe] // Caucasian Entomological Bulletin. Vol.3. No.1. P.3-7 [in Russian, with English summary].

Ponomarev A.V., Abdurakhmanov G.M. 2014. [Spiders (Aeanei) of North Caspian coast and islands] // Yugh Rossii: ekologiya, razvitie. No.1. P.76-121 [in Russian, with English summary].

Ponomarev A.V., Abdurakhmanov G.M., Alieva S.V., Dvadnenko K.V. 2011a. [Spiders (Arachnida: Aranei) of the coastal and island territories of northern Dagestan] // Yugh Rossii: ekologiya, razvitie. No.4. P.126-143 [in Russian, with English summary].

Ponomarev A.V., Aliev M.A., Khabiev G.N. 2017. [Spiders (Aranei) of the site "Sarykum sand dune" nature reserve "Dagestan"] // Trudy gosudarstvennogo prirodnogo zapovednika "Dagestansky". Iss.13. P.28-45 [in Russian].

Ponomarev A.V., Aliev M.A., Khalidov A.K., Shavlukov Z.A. 2011b. [Supplementary Data on the Spider Fauna (Aranei) of Dagestan] // D.M. Mallaev et al. (eds.). Sovremennye problemy biologii i ekologii: materialy dokladov Mezhdunarodnoi nauchno-prakticheskoi konferentsii, 10-12 marta 2011 g. [Modern Problems in Biology and Ecology: Material Reports at the International scientific-practical Conference, 10-12 March 2011]. Makhachkala: Dagestan State Pedagogic University. P.77-82 [in Russian].

WSC 2019. World Spider Catalog. Version 20.0. Natural History Museum Bern, online at http://wsc.nmbe.ch, accessed on 15.03.2019. doi: $10.24436 / 2$

Responsible editor D.V. Logunov 